\title{
Antiproliferative Effect of Retinoid Compounds on Kaposi's Sarcoma Cells
}

\author{
Jacques Corbeil, * Eric Rapaport, ${ }^{*}$ Douglas D. Richman, ${ }^{* \$ \$}$ and David J. Looney \\ Departments of ${ }^{*}$ Pathology and ${ }^{\ddagger}$ Medicine, University of California San Diego, La Jolla, California 92093 ; and ${ }^{\S}$ San Diego Veterans \\ Affairs Medical Center, San Diego, California 92161
}

\begin{abstract}
A panel of retinoid compounds (tretinoin, isotretinoin, acitretin, and RO13-1470) were tested for inhibitory activity against Kaposi's sarcoma cell (KSC) cultures in vitro. Tretinoin was found to be the most effective retinoid tested, inhibiting the growth of KSC in vitro while having no effect on the expression of interleukin- 6 and basic fibroblast growth factor, two important cytokines involved in KSC growth. Tretinoin also did not appear to downregulate the expression of receptors for these two cytokines. At low concentrations $\left(10^{-9} \mathrm{M}\right)$, acitretin and tretinoin selectively inhibited growth of early passage KSC. At higher concentrations $\left(10^{-6}-10^{-5} \mathrm{M}\right)$, retinoid treatment induced a pattern of DNA degradation and morphological changes in KSC characteristic of apoptosis (programmed cell death). The inhibitory activity of tretinoin on KSC growth was decreased if human serum (but not fetal calf serum) was present in the growth medium, and partially restored by removal of serum lipids. These data suggest that retinoids possess potential as therapeutic agents in Kaposi's sarcoma. (J. Clin. Invest. 1994. 93:1981-1986.) Key words: Kaposi's sarcoma • retinoids - chemotherapy • apoptosis • AIDS
\end{abstract}

\section{Introduction}

Kaposi's sarcoma (KS) ${ }^{1}$ is epidemic in HIV-infected individuals. A substantial proportion of homosexual males with AIDS (15-18\%) experience clinical complications due to KS during the course of their disease (1-3). Autopsy series have shown an even higher prevalence $(59-95 \%)$ in this group $(4,5)$. A growing body of evidence on the growth characteristics of KS cells cultured in vitro indicates the importance of autocrine pathways in regulation of proliferation, including prominent roles played by IL-6, basic fibroblast growth factor (bFGF), Oncostatin M, and PDGF, as well as the HIV-1 tat protein (6-14). Therapy, including the use of vinca alkaloids, radiotherapy, interferon-alpha, and others, alone and in combination, has been directed towards palliation of both cutaneous and visceral disease (15-21).

Retinoids are pharmacologic compounds derived from vitamin A (retinol), which plays a critical role in growth, repro-

Address correspondence to Dr. Jacques Corbeil, Department of Medicine 0679, University of California San Diego, La Jolla, CA 920930679.

Received for publication 4 August 1993 and in revised form 18 January 1994

1. Abbreviations used in this paper: bFGF, basic fibroblast growth factor; HUVEC, human umbilical vein endothelial cells; KSC, Kaposi's sarcoma cell; PI, propidium iodine.

The Journal of Clinical Investigation, Inc.

Volume 93, May 1994, 1981-1986 duction, differentiation, and immune response, and may contribute in limiting the growth of certain malignancies. Retinoids have been used in the treatment of a variety of malignancies, including $\mathrm{KS}$, with mixed results (22-26). The effects of retinoids are mediated by two families of nuclear retinoic acid receptors (27-30) (RAR- $\alpha,-\beta,-\gamma$ and $\operatorname{RxR} \alpha$ ). Retinoids have been shown to inhibit the growth of human melanoma cell lines by downregulating IL-6 receptors (31), providing a rationale for the investigation of retinoid compounds as therapeutics in KS. Promising results have been obtained with topical monotherapy of KS with tretinoin (32).

In this laboratory, KS cell (KSC) cultures derived from pleural fluid and cutaneous or mucosal biopsies have been successfully established, including KSC cell cultures from both HIV-positive and -negative individuals. To determine the response of these KSC cultures to retinoids, KSC were treated with graded concentrations of a representative panel of retinoids (tretinoin, isotretinoin, acitretin, and Ro13-1470), and inhibition of proliferation and cytotoxicity was correlated with the effects of retinoid treatment on IL- 6 and bFGF, and their receptors.

\section{Methods}

Cell culture. $\mathrm{KSCl}$ was obtained from a explant of a biopsy obtained from a young HIV-1-negative homosexual male with KS principally involving the trunk and upper extremities. $\mathrm{KSC} 2,3$, and 4 were obtained from HIV-infected homosexual men by explant from biopsies from cutaneous lesions of disseminated HIV-associated KS. All explants were grown in D-valine (GIBCO BRL, Gaithersburg, MD) DMEM supplemented with $10 \%$ endothelial cell-conditioned medium and $1 \%$ Condimed (Boeringer Mannheim Biochemicals, Indianapolis, IN). Human umbilical vein endothelial cells (HUVEC) were purchased at passage 2 from Clonetics (San Diego, CA). The smooth muscle cell line SKLMS-1 and the fibroblast cell line CCD34Lu were obtained from the American Type Culture Collection (Rockville, MD). For all studies, cells were passaged using an enzymatic preparation capable of releasing the cells from the substratum (Passage-ease; Vectec, Schenectady, NY) and grown in EGM (Clonetics) that contains $2 \%$ fetal bovine serum supplemented with epidermal growth factor ( 10 $\mathrm{ng} / \mathrm{ml})$, hydrocortisone $(1 \mu \mathrm{g} / \mathrm{ml})$, and a bovine brain extract $(12$ $\mu \mathrm{g} / \mathrm{ml})$ containing heparin $(10 \mu \mathrm{g} / \mathrm{ml})$ and the antibiotics gentamicin $(50 \mu \mathrm{g} / \mathrm{ml})$ and amphotericin-B $(50 \mathrm{ng} / \mathrm{ml})$. Alternatively, the cells were grown in Endothelial-serum-free media (SFM) supplied by GIBCO BRL for the thymidine uptake assay.

Chemicals. Tretinoin (all-trans-retinoic acid); isotretinoin (13-cisretinoic acid); acitretin ([all-trans-9 (4-methoxy-2,3,6-trimethylphenyl)-3,7-dimethyl-2,4,6,8-nonatetraenoic acid] and RO13-7410 (p-[(E)-2-(5,6,7,8-tetrahydro-5,5,8,8-tetra methyl-2-naphthyl)-1propenyl] benzoic acid) were obtained from Roche Products (Dee Why, Australia). The compounds were dissolved in DMSO at $10^{-2} \mathrm{M}$ and diluted in the culture media at the final dilution used. The stock solutions were stored at $-70^{\circ} \mathrm{C}$ protected from light and oxygen.

Apoptosis assay. Treated and controls cells were released from the substratum using Passage-ease and fixed in $30 \%$ ethanol in PBS. Propidium iodine (PI) was added for $30 \mathrm{~min}$ at a concentration of 50 $\mu \mathrm{g} / \mathrm{ml}$ in PBS containing $0.1 \%$ Triton $\mathrm{X}-100,0.1 \mathrm{mM} \operatorname{EDTA}(\mathrm{Na})_{2}$, 
and RNAse at $50 \mu \mathrm{g} / \mathrm{ml}(50 \mathrm{U} / \mathrm{mg})$. The cells were washed twice in PBS and analyzed in a FACS ${ }^{\circledR}$ (Becton Dickinson \& Co., Mountain View, CA) using a cell cycle analysis doublet discrimination protocol (33).

$\left[{ }^{3} H\right]$ Thymidine uptake assay. Cells (KSC, fibroblasts, smooth muscle cells, and HUVEC) were plated in 96-well plates (previously coated with fibronectin for KS and HUVEC) at a density of 3,000 5,000 cells/well. The cells were maintained in endothelial serum-free medium (GIBCO BRL) for the duration of the experiment. Controls included endothelial-SFM, and endothelial-SFM with DMSO added to the same final concentration present in each corresponding dilution of retinoid solution ( $14 \mathrm{mM}$ DMSO for $10^{-5}$ retinoid dilutions, $140 \mu \mathrm{M}$ DMSO for $10^{-7}$ retinoid dilutions, and $1.4 \mu \mathrm{M}$ DMSO for $10^{-9}$ retinoid dilutions). Acitretin, tretinoin, isotretinoin, Ro 13-7410, and DMSO were diluted in endothelial-SFM to obtain concentrations of $10^{-5}, 10^{-7}$, and $10^{-9} \mathrm{M}$ of each retinoid ( $14 \mathrm{mM}, 140 \mu \mathrm{M}$, and $1.4 \mu \mathrm{M}$ DMSO, respectively), and $200 \mu \mathrm{l}$ was added to each well. $\left[{ }^{3} \mathrm{H}\right]-$ thymidine (specific activity, $20 \mathrm{mCi} / \mathrm{ml}$ ) was added to a final concentration of $2 \mu \mathrm{Ci} /$ well $(0.2 \mu \mathrm{Ci} / \mathrm{ml}$ for the HUVEC). Each experimental condition was assayed in quadruplicate. After $2 \mathrm{~d}$, the cells were rinsed once with M199 and $200 \mu$ lo a solution of trypsin-EDTA (GIBCO BRL) was added to release the adherent cells from the matrix. The cells were harvested using a Skatron harvester, and the radioactive signal was determined by placing the filters in $5 \mathrm{ml}$ of Ready-Safe cocktail (Beckman Instruments, Fullerton, CA) followed by counting in the tritium channel of a scintillation counter (ICN Micromedic, Huntsville, $\mathrm{AL}$ ). The resulting counts for each experimental condition were the mean of quadruplicates. The percentage of control was obtained by dividing the mean of a condition by the value obtained for the DMSO control without retinoid.

PCR $m R N A$ analysis. Total RNA was isolated by the method of Chomczynski and Sacchi (34) from $3 \times 10^{6}$ cells and stored in the form of an ethanol precipitate at $-20^{\circ} \mathrm{C}$. For DNase I treatment, $5 \mu \mathrm{g}$ of total RNA was dissolved in $100 \mu \mathrm{l}$ DNase digestion buffer ( $10 \mathrm{mM}$ Tris$\mathrm{HCl}, \mathrm{pH} 7.4,10 \mathrm{mM} \mathrm{MgCl}, 1 \mathrm{mM}$ DTT) containing $2 \mathrm{U} / \mu$ l RNase free DNase I (Boehringer Mannheim Biochemicals) and $0.4 \mathrm{U} / \mu \mathrm{l}$ RNasin (Boehringer Mannheim Biochemicals), and incubated for 45 min at $37^{\circ} \mathrm{C}$. RNA was extracted once each with phenol followed by phenol-chloroform, and precipitated with ethanol, and resuspended in $12 \mu$ l DEPC-treated distilled water.

Template primer $(1 \mu \mathrm{l}=500 \mathrm{ng})$ oligo(dT) 12-18 (Clontech) was added to the RNA ( $10 \mu \mathrm{l})$ and the sample was heated to $65^{\circ} \mathrm{C}$ for $5 \mathrm{~min}$, and allowed to cool for $10 \mathrm{~min}$ to allow for primer annealing. A final volume of $25 \mu \mathrm{l}$ was obtained after the addition of $12 \mu \mathrm{l}$ reverse transcriptase buffer ( $50 \mathrm{mM}$ Tris- $\mathrm{HCl}$, pH 8.3, $75 \mathrm{mM} \mathrm{KCl,} 3 \mathrm{mM} \mathrm{MgCl}_{2}$, $1 \mathrm{mM}$ DTT) containing $2 \mathrm{U}$ Moloney murine leukemia virus reverse transcriptase (Boehringer Mannheim Biochemicals), $20 \mathrm{U}$ RNasin (Boehringer Mannheim Biochemicals), and $0.6 \mathrm{mM}$ of each deoxyribonucleoside triphosphate (dNTP). The sample was then incubated at $37^{\circ} \mathrm{C}$ for $1 \mathrm{~h}$. Oligonucleotides were synthesized using a oligosynthesizer (Pharmacia Fine Chemicals, Piscataway, NJ) and deprotected in ammonium hydroxide and ethanol precipitated and washed before aliquoting and freezing at $50 \mathrm{pM} / \mathrm{ml}$. The sequences of the gene-specific primers and the size of the segments defined were as follows: IL- 6 sense $5^{\prime}$ atg-aac-tcc-ttc-tcc-aca-agc-gc 3', IL-6 antisense 5' gaa-gag-ccc-tcaggc-tgg-act-g 3', 628-bp product; $\alpha$-subunit IL-6 receptor sense $5^{\prime}$ gttcaa-gaa-gac-gtg-gaa-gc 3', $\alpha$-subunit IL-6 receptor antisense $5^{\prime}$ ctg-ggcatt-tgg-aaa-gc 3', 464-bp product; bFGF sense 5' atg-gca-gcc-ggg-agcatc-acc-acg-3', bFGF antisense 5' tca-gct-ctt-agc-aga-cat-tgg-aag 3', 478-bp product; bFGF receptor (flg) sense $5^{\prime}$ tct-atc-gga-ctc-tcc-cat-c 3', bFGF receptor (flg) antisense 5' aag-aac-ccc-aga-gtt-cat-g 3', 291-bp product; $\beta$-actin sense $5^{\prime}$ cgt-ggg-gcg-ccc-cag-gca-cca-g 3', $\beta$-actin antisense $5^{\prime}$ ctc-ctt-aat-gtc-acg-cac-gat-ttc $3^{\prime}$, 548-bp product. PCRs were performed in $100-\mu$ l volumes using a Programmable Cyclic Reactor (Ericomp, San Diego, CA). $2 \mu \mathrm{l}$ of the reverse transcription reactions was used as template. A negative control with no template and a positive control with $1 \mu \mathrm{g}$ of human genomic DNA were included in all reaction sets. The amplification reaction contained $2.5 \mathrm{U}$ Taq DNA polymerase (Boehringer Mannheim Biochemicals), $200 \mu \mathrm{M}$ of each dNTP, $100 \mathrm{pmol}$ of each primer, $10 \mathrm{mM}$ Tris- $\mathrm{HCl}, \mathrm{pH} 8.3,50 \mathrm{mM}$ $\mathrm{KCl}, 1.5 \mathrm{mM} \mathrm{MgCl}_{2}$, and $0.1 \mathrm{mg} / \mathrm{ml}$ gelatin. The reaction mixture was overlaid with $100 \mu \mathrm{l}$ mineral oil and subjected to an initial denaturation step followed by 35 cycles of $30 \mathrm{~s}$ at $94^{\circ} \mathrm{C}, 30 \mathrm{~s}$ at $55^{\circ} \mathrm{C}$, and $1 \mathrm{~min}$ at $72^{\circ} \mathrm{C}$, with a final 7 -min extension step at $72^{\circ} \mathrm{C}$. Aliquots $(12 \mu \mathrm{l})$ of the PCR products were subjected to electrophoresis in a $1.2 \%$ agarose gel (FMC Bioproducts, Rockland, ME) with predigested lambda molecular weight markers and $0.5 \mu \mathrm{g} / \mathrm{ml}$ ethidium bromide and visualized under UV light.

Quantification of IL-6. IL-6 ELISA was performed on culture supernatants ( stored at $-80^{\circ} \mathrm{C}$ ) as described by the manufacturer ( $R \& D$ Research, Minneapolis, MN). This assay uses a polyclonal capture antibody and monoclonal antibodies for detection (35).

\section{Results}

The effect of four retinoid compounds on the proliferative response of cultures of three KS cell strains and control cells (endothelial cells, smooth muscle cells, and fibroblasts) was determined by using a standard $\left[{ }^{3} \mathrm{H}\right]$ thymidine uptake assay. All of the compounds tested, with the exception of acitretin, inhibited the growth rate of KSC1 by $50-70 \%$ at $10^{-5} \mathrm{M}$ (Fig. 1 $A)$. The retinoid effects were negligible at the lower concentrations of $10^{-7}$ and $10^{-9} \mathrm{M}$. The proliferation rates of KSC2 (Fig. $1 B$ ) and KSC4 (Fig. $1 E$ ) were also reduced, but to a lesser extent, ranging from 20 to $90 \%$ depending on the compound and concentration assayed. The KSC 3 culture (Fig. $1 C$ ) was sensitive to the action of the retinoids. Both tretinoin and acitretin produced $>90 \%$ inhibition of growth at nanomolar concentrations. A stimulatory effect on $\mathrm{KSC} 3$ growth was seen at the lowest concentrations tested for two of the compounds (RO13-1470 and isotretinoin). Note that the efficacy of retinoids generally decreased with passage number of $\mathrm{KSC}$ in vitro (see Fig. $1 C$, passage 4; and Fig. $1 D$, passage 6); therefore, KSC used in subsequent experiments were all used at less than eight in vitro passages.

To approach the question of specificity of inhibition of KSC, the retinoids were also tested for their growth inhibitory capabilities on other cell types. The smooth muscle cell line SKLMS-1 (Fig. $2 A$ ) was inhibited (up to $90 \%$ ) in a fashion similar to the (less-sensitive) KSC. Primary endothelial cells (Fig. $2 B$ ) were found to be strongly inhibited by retinoids. In contrast, the fibroblast cell line CCD34lu was refractory to inhibition by the retinoids tested (Fig. $2 C$ ).

Because retinoids are bound by several serum proteins ( 36 , 37 ), the effect of the presence of serum on retinoid action was investigated. FBS had little effect on the inhibition produced by retinoids (not shown); however, growth inhibition produced by tretinoin was reduced from 83 to $35 \%$ by addition of $10 \%$ heat-inactivated whole human serum to the culture medium. The addition of $10 \%$ human serum that had been delipidized using the methylethylketone extraction procedure ( 38 ) yielded intermediate values $(56 \%)$ of inhibition, demonstrating the presence of an inhibitory factor(s) in normal human serum at least partially resistant to lipid extraction.

The morphological appearance of KSC revealed that most of the cells in treated cultures (tretinoin at $10^{-5} \mathrm{M}$ ) became detached, rounded-up, and floated in the culture medium within 48-72 $\mathrm{h}$ after initiation of treatment (Fig. 3). The morphology suggested the possibility that retinoids might be inducing apoptosis in treated KSC. Both attached and floating cells were analyzed for viability by trypan blue dye exclusion, and for DNA fragmentation by PI ( a DNA intercalative fluorescent 
A

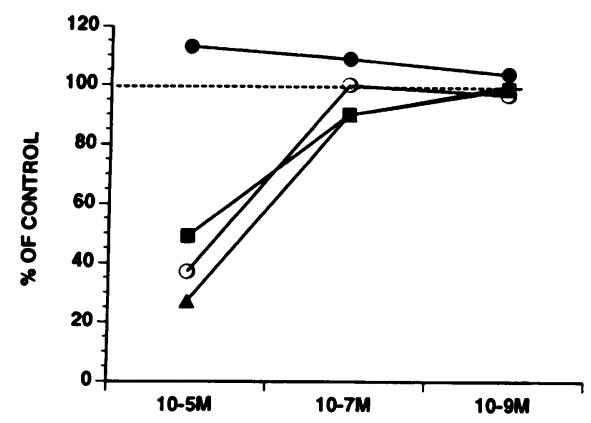

C
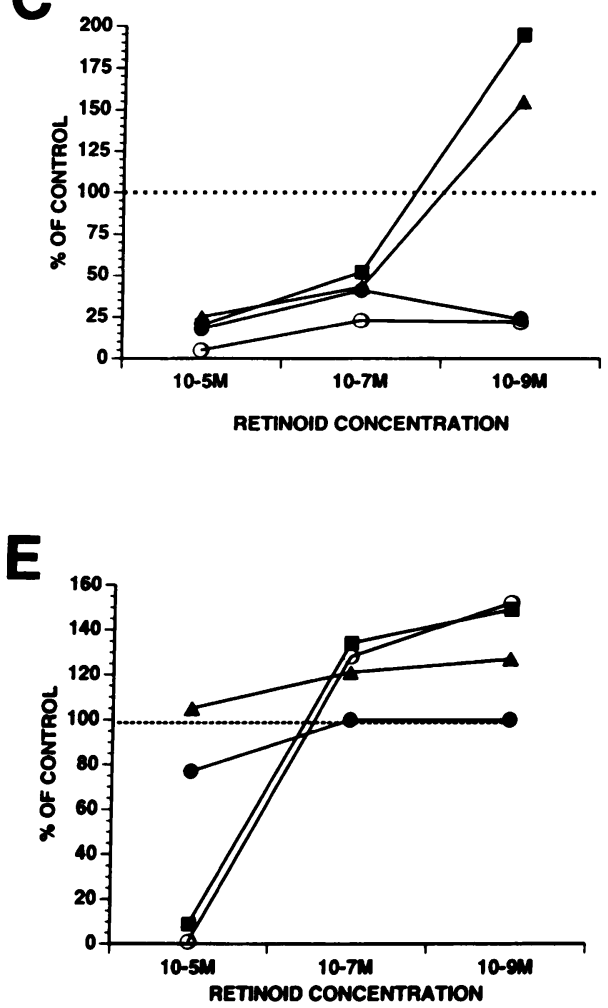

B

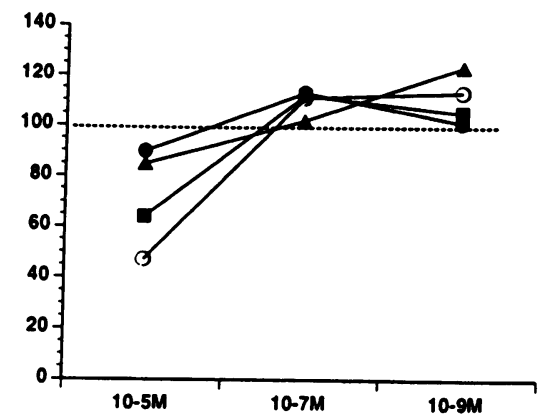

D

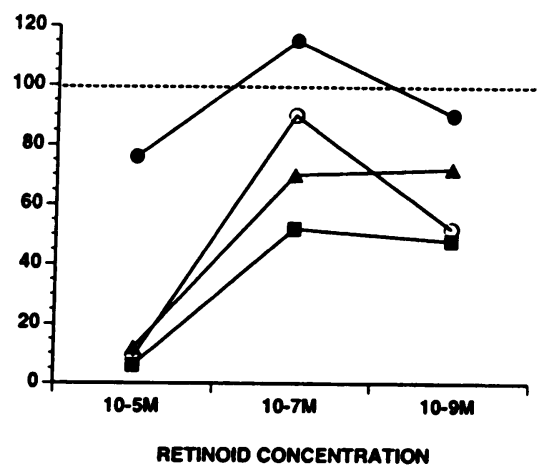

Figure 1. Effect of retinoids on KS cell cultures. Shown is the $\left[{ }^{3} \mathrm{H}\right]-$ thymidine uptake of treated KSC cultures expressed as a percentage of the uptake of cells treated with the corresponding concentration of DMSO (see Methods). All assays were performed in quadruplicate. (A) $\mathrm{KSCl}$, passage 6, derived from an explant of a cutaneous lesion of an HIV-1-seronegative homosexual male; $(B) \mathrm{KSC} 2$, passage 6, derived from an explant of a cutaneous lesion from a HIV-1-seropositive subject; (C) KSC3, passage 4, (from HIV-1-positive subject; $(D) \mathrm{KSC} 3$, passage 6; (E) KSC4, passage 6. Cells were cultured in the presence of the stated concentrations of $(\bullet)$ acitretin, ( $(0)$ tretinoin, $(\square)$ isotretinoin, and ( $\Delta$ ) Rol3-7410. Note the consistent inhibitory action of tretinoin $(A-E)$, and the effect of additional in vitro passage on the sensitivity of $\mathrm{KSC} 3$ cells $(C$ and $D)$.
A

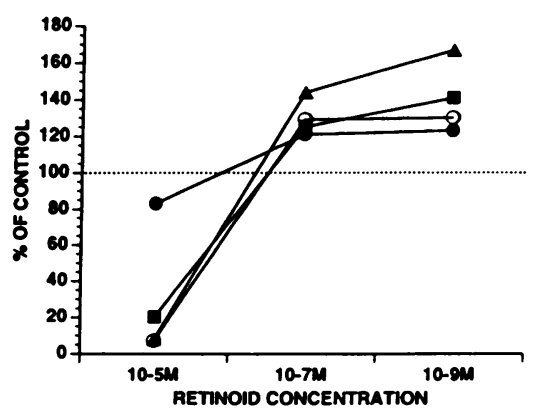

$\mathbf{B}$

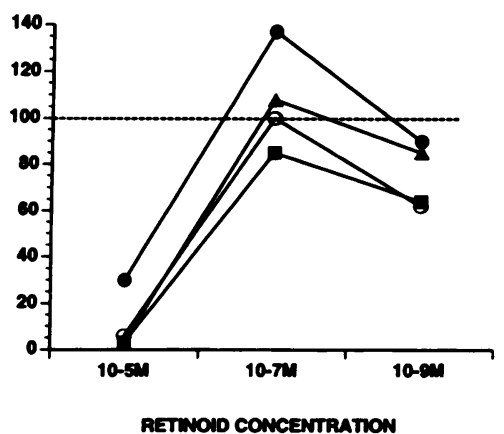

C

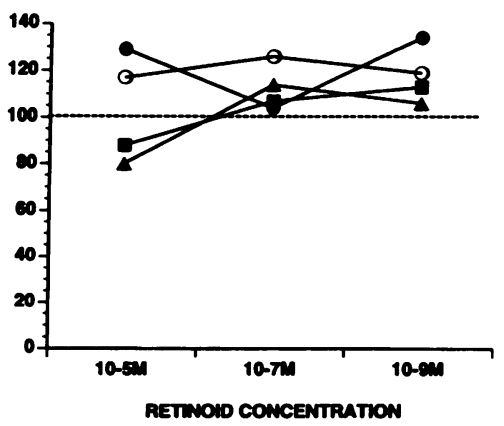

Figure 2. Effect of retinoids on other mesenchymal cells. Shown is the $\left[{ }^{3} \mathrm{H}\right]$ thymidine uptake of treated cell cultures as in Fig. 1 . $(A)$ Human smooth muscle cells derived from labial leiomyosarcoma (SKLMS-1); $(B)$ HUVEC; and $(C)$ human lung fibroblasts (CCD34Lu). Smooth

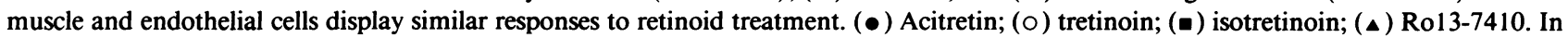
contrast, note the resistance of fibroblasts to retinoid induced inhibition of proliferation. 

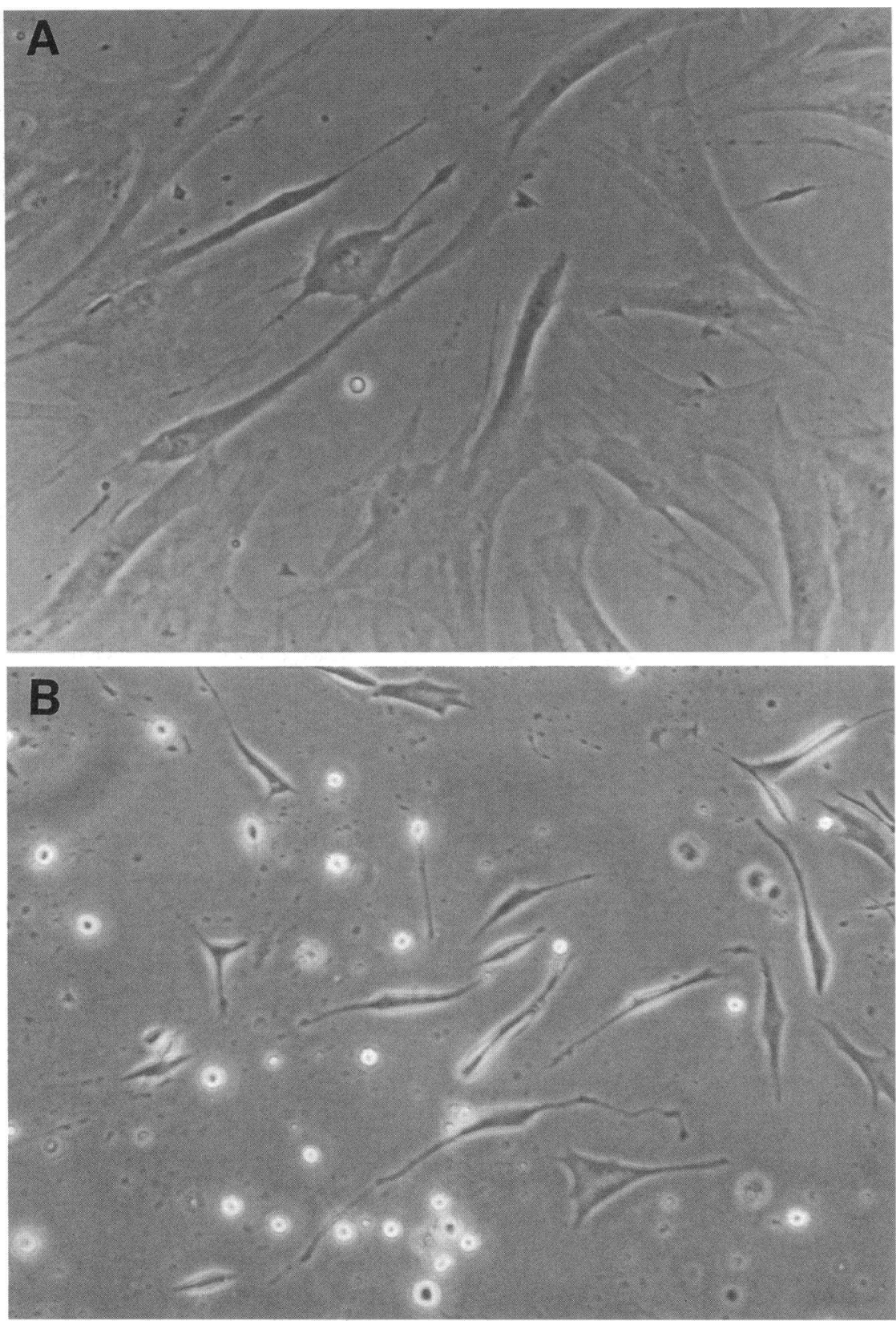

Figure 3. Morphological changes induced by retinoid treatment. KSC3 cells, passage 6 , were treated with tretinoin or DMSO alone for $48 \mathrm{~h}$. (A) Tretinoin $\left(10^{-5} \mathrm{M}\right), \times 50$; $(B)$ DMSO control, $\times 50$. Note rounding and detachment of cells. dye) staining and flow cytometric analysis. While trypan blue was excluded by $>98 \%$ of all cell populations, indicating that the membrane was still functionally intact, PI staining revealed a pattern of DNA fragmentation suggestive of the induction of programmed cell death in treated KSC. The attached cell population constituted $80 \%$ of the treated cells and $100 \%$ of the control cells. In both treated and control cell cultures, few attached cells were found to be apoptotic ( $4 \%$ of treated cells and $3 \%$ of control cells). In the detached cell population, representing $20 \%$ of the total treated cells, significantly more cells (22\%) were found to display staining characteristic of apoptosis.

The effects of retinoids on the expression of mRNA for IL-6 and bFGF as well as their respective receptors were analyzed in an attempt to correlate the growth inhibition with regulation of cytokines and their receptors. Tretinoin at $10^{-5} \mathrm{M}$ had no discernible effect on the level of mRNA expression of the bFGF receptor (Fig. 4) at $48 \mathrm{~h}$, and bFGF expression was actually elevated in $\mathrm{KSCl}$ (Fig. 4, lanes 9). The pattern of effects on
IL-6 messages was slightly more complex. IL-6 expression was clearly enhanced by tretinoin treatment in $\mathrm{KSCl}$ cultures ( Fig. 4 , lanes 9), but only a marginal increase in IL-6 receptor message was seen between retinoid- and DMSO-treated control KSC 3 cells (Fig. 4, lanes 5 and 6). IL-6 receptor expression was decreased in control endothelial cells when treated with tretinoin (Fig. 4, lanes 1-3). This is made more difficult to interpret in view of the lower constitutive expression of IL-6 receptor in KSC3 cultures (Fig. 4, lanes 4), in comparison with $\mathrm{KSC} 1$ cells (Fig. 4, lanes 7).

The level of mRNA for IL-6 as measured by RNA PCR correlated with the protein expression as measured by ELISA (Fig. 5). A tretinoin concentration of $10^{-6} \mathrm{M}$ was used to prevent extensive cell death, although effects on the morphology of the cells could readily be seen at this concentration. An increase in IL-6 production was noted in retinoid-treated KSC1. This cell culture, derived from an HIV-negative individual, is not a high producer of IL-6, a hallmark of KS cell culture in 
IL-6

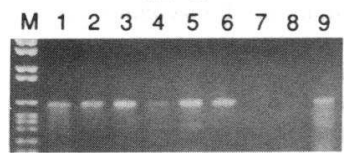

bFGF

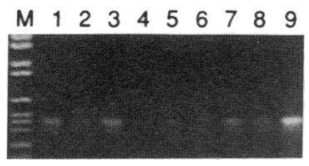

Actin

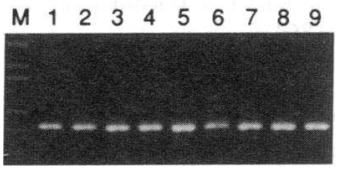

Figure 4. Analysis of cytokine and cytokine receptor mRNA. Total RNA was isolated from $3 \times 10^{6}$ cells, treated with RNAase-free DNAase, and reverse transcribed and amplified by PCR with the respective primer pairs ( 35 cycles) as described in Methods. Products were analyzed by agarose gel electrophoresis and ethidium bromide staining as shown. All reactions were performed at least in duplicate, and similar results were obtained in analysis of independent experiments. Lanes $M$, molecular weight markers (pBR328 Bgl I/Hinf I digested, bands of $2176,1766,1230,1033,653,517,453,394,298$, 234/220; 154 bp). Lanes 1-3, HuVEC p4; lanes 4-6, KSC3; lanes $7-9, \mathrm{KSCl}$; lanes 1,4 , and 7, control cells (neither DMSO nor tretinoin); lanes 2, 5, and 8 , DMSO (equivalent dilution $=1.4 \mathrm{mM} / 48$ h)-treated control; lanes 3,6 , and 9 , tretinoin treated $\left(10^{-6} \mathrm{M} / 48\right.$ h). The level of mRNA for actin (ACTIN panel) was used to provide a crude estimate that sufficient amounts of input RNA were used for each sample.

general. The response of these cells to retinoids, with respect to IL-6 production, appeared to be similar to those of fibroblasts (not shown). The production of IL-6 message in endothelial control cell cultures (HUVEC) was inhibited by the tretinoin treatment, while the constitutive production of IL- 6 by KSC3 and KSC4 remained unaffected by retinoid treatment.

\section{Discussion}

The present study revealed that some KSC are relatively sensitive to the action of retinoids, while others are no more sensitive to inhibition by retinoids than normal endothelial or smooth muscle cells. Concentrations as low as $10^{-9} \mathrm{M}$ were sufficient to significantly inhibit the growth of early passage $\mathrm{KSC}$, a concentration that is pharmacologically achievable with oral systemic therapy. More rapidly dividing early passage $\mathrm{KS}$ cells were found to be more sensitive to retinoids, suggesting that KSC may actually be quite susceptible to inhibition by retinoids in vivo. Further studies are needed to more definitively address the effect of in vitro passage on KS cell responses.

Antiproliferative effects observed on endothelial cells (HUVEC) and the smooth muscle cells (SKMLS-1) may be of little consequence therapeutically, as the growth of these cells is very tightly regulated in vivo. The lack of effect of retinoid treatment on the growth of lung fibroblasts (CCD34Lu) may be due to differential expression of nuclear retinoid receptors, or an interaction with other specific factor(s) present in these cells.

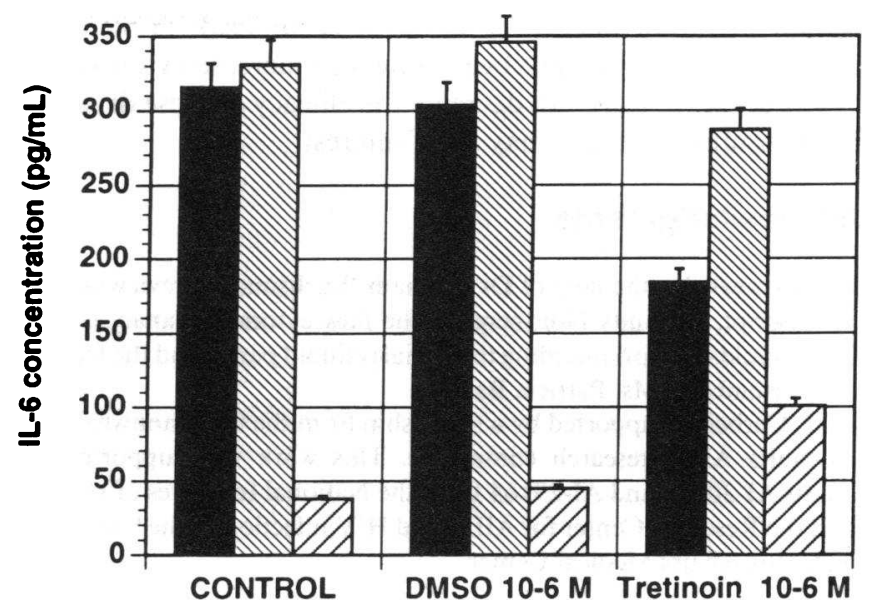

Figure 5. IL-6 Production by KS cells treated with tretinoin. A commercial EIA (R\&D Systems) was used to determine the concentrations of IL- 6 produced by $\mathrm{KSC} 3, \mathrm{KSCl}$, and HUVE cell cultures in the presence of serum-free endothelial cell medium alone (Control, left), DMSO control (middle), and tretinoin $\left(10^{-6} \mathrm{M}\right.$, right $)$. ( $(\bullet)$ HUVEC; (-) KSC3; ( $)$ KSC1.

A distinct IL-6 phenotype was observed in KSC3, a KSC derived from an HIV-positive individual, compared with KSC1 (derived from an HIV-negative homosexual man with KS) and KSC4 (derived from an explant of another HIV-1-positive individual). The $\mathrm{KSC} 3$ culture constitutively produced significantly more IL-6 than $\mathrm{KSC} 1$, and while IL-6 expression was increased by retinoid treatment in $\mathrm{KSCl}$, it was slightly reduced in $\mathrm{KSC} 3$ cells treated with tretinoin. IL-6 production remained unaffected by tretinoin $\left(10^{-5} \mathrm{M}\right)$ treatment. This finding suggested the possibility that the importance of the IL-6 autocrine pathway might differ between $\mathrm{KS}$ cultures derived from different individuals.

The antiproliferative effect of retinoids on KSC did not appear to be mediated by the downregulation of IL-6 or bFGF, two of the main cytokines involved in the pathogenesis of $\mathrm{KS}$ $(7,8,13)$. In addition, the analysis of the receptor expression for IL-6 as well as bFGF revealed no alteration by retinoids despite a substantial decrease in proliferative rate. The antiproliferative effects of retinoids may be due to alterations in expression of a number of other cytokines or receptors, possibly including uncoupling of oncostatin $\mathbf{M}$ production from the IL-6 autocrine pathway or upregulation of TGF- $\beta$, a natural growth inhibitor of endothelial cell proliferation, or expression of TGF- $\beta$ receptors (39). Retinoids $\left(10^{-5} \mathrm{M}\right)$ induced apoptosis in KSC, consistent with induction of programmed cell death by withdrawal of growth factor(s).

A careful correlation of the clinical response of $\mathrm{KS}$ to treatment with topical or systemic retinoids with in vitro sensitivity would appear to be of value in discerning the mechanism of action of retinoids against $\mathrm{KS}$ in vivo. In addition, the efficacy of the treatment might be increased if in vitro testing could identify compounds with a greater potential therapeutic index (specificity for KSC) or compounds that are not inhibited by factors present in plasma or serum. The action of retinoids combined with other drugs in vitro is another area for future investigation that may have therapeutic implications. In this regard, the combination of retinoid treatment with antisense oligodeoxynucleotides directed against IL- 6 or bFGF, antiangiogenic agents (e.g., the sulfated polyglycan SPPG), or with 
certain chemotherapeutic agents such as etoposide or bleomycin (where retinoids have been shown to increase cytotoxicity in RA-sensitive cells, but decrease the efficacy of these drugs in RA-resistant cells (40) may be of interest.

\section{Acknowledgments}

We acknowledge the help of Dr. William Wachsman in reviewing the manuscript, Dr. Judy Nordberg for the flow cytometric analysis, Dr. David Goldstein for providing the initial retinoid panel, and the technical assistance of Ms. Patricia Badel.

J. Corbeil is supported by a fellowship from the Commonwealth of Australia AIDS research committee. This work was supported by grants AI-30457 and AI-29164 from the National Institutes of Health, and the Research Center for AIDS and HIV infection of the San Diego Veterans Affairs Medical Center.

\section{References}

1. Rabkin, C. S., R. J. Biggar, and J. W. Horm. 1991. Increasing incidence of cancers associated with the human immunodeficiency virus epidemic. Int. J. Cancer. 47:692-696.

2. Drew, M. L., J. Mills, L. B. Hauer, R. C. Miner, and R. Rutherford. 1988. Declining prevalence of Kaposi's sarcoma in homosexual AIDS patients paralleled by fall in cytomegalovirus transmission. Lancet. i:66.

3. Longo, D. L., R. C. Steis, and H. C. Lane. 1984. Malignancies in the AIDS patient: natural history, treatment strategies and preliminary results. In I. J. Selikoff, A. S. Teirstein, and S. Z. Hirschman, editors. Ann. NY Acad. Sci. 437:421429.

4. McKenzie, R., W. D. Travis, S. A. Dolan, S. Pittaluga, I. M. Feuerstein, J. Shelhamer, R. Yarchoan, and H. Masur. 1991. The causes of death in patients with human immunodeficiency virus infection: a clinical and pathologic study with emphasis on the role of pulmonary diseases. Medicine (Baltimore). 70:326343.

5. Niedt, G. W., and R. A. Schinella. 1985. Acquired immunodeficiency syndrome: clinicopathological study of 56 autopsies. Arch. Pathol. Lab. Med. 109:727-734.

6. Nakamura, S., S. Z. Salahuddin, P. Biberfeld, B. Ensoli, P. D. Markham, F. Wong-Stall, and R. C. Gallo. 1988. Kaposi's sarcoma cells: long-term culture with growth factor from retrovirus-infected CD4+ T cells. Science (Wash. DC). 242:426-430.

7. Miles, S. A., A. R. Rezai, J. F. Salazar-Gonzalez, M. Vander Meyden, R. H. Stevens, D. M. Logan, R. T. Mitsuyasu, T. Taga, T. Hirano, and T. Kishimoto. 1990. AIDS Kaposi's sarcoma-derived cells produce and respond to interleukin6. Proc. Natl. Acad. Sci. USA. 87:4068-4072.

8. Corbeil, J., L. Evans, E. Vasak, D. A. Cooper, and R. Penny. 1991. Culture and properties of cells derived from Kaposi's sarcoma. J. Immunol. 146:29722976.

9. Roth, W. K., S. Werner, C. G. Schirren, and P. H. Hofschneider. 1989. Depletion of PDGF from serum inhibits growth of AIDS-related and sporadic Kaposi's sarcoma cells in culture. Oncogene. 4:483-487.

10. Sturzl, M., W. K. Roth, N. H. Brockmeyer, C. Zietz, B. Speiser, and P. H. Hofschneider. 1992. Expression of platelet-derived growth factor and its receptor in AIDS-related Kaposi sarcoma in vivo suggests paracrine and autocrine mechanisms of tumor maintenance. Proc. Natl. Acad. Sci. USA. 89:7046-7050.

11. Miles, S. A., O. Martinez-Maza, A. Rezai, L. Magpantay, T. Kishimoto, S. Nakamura, S. F. Radka, and P. S. Linsley. 1992. Oncostatin M as a potent mitogen for AIDS-Kaposi's sarcoma derived cells. Science (Wash. DC). 255:1432-1434.

12. Nair, B. C., A. L. DeVico, S. Nakamura, T. D. Copeland, Y. Chen, A. Patel, T. O'Neil, S. Oroszlan, R. C. Gallo, and M. G. Sarngadharan. 1992. Identification of a major growth factor for AIDS-Kaposi's sarcoma cells as oncostatin M. Science (Wash. DC). 255:1430-1432.

13. Ensoli, B., S. Nakamura, S. Z. Salahuddin, P. Biberfeld, L. Larsson, B. Beaver, F. Wong-Staal, and R. C. Gallo. 1989. AIDS-Kaposi's sarcoma-derived cells express cytokines with autocrine and paracrine growth effects. Science (Wash. DC). 243:223-226.

14. Ensoli, B., G. Barillari, S. Z. Salahuddin, R. C. Gallo, and F. Wong-Staal. 1990. Tat protein of HIV-1 stimulates growth of cells derived from Kaposi's sarcoma lesions of AIDS patients. Nature (Lond.). 345:84-86.

15. Epstein, J. B., and C. Scully. 1989. Intralesional vinblastine for oral Kaposi's sarcoma in HIV infection. Lancet. ii:1100-1101.

16. Geara, F., J. P. LeBourgeois, P. Piedbois, J. M. Pavlovitch, and J. J. Mazerow. 1991. Radiotherapy in the management of cutaneous epidemic Kaposi's sarcoma. Int. J. Radiat. Oncol. Biol. Phys. 21:1517-1522.

17. Kahn, J. O., L. D. Kaplan, P. A. Volberding, J. L. Ziegler, S. Crowe, S. R.
Saks, and D. I. Abrams. 1989. Intralesional recombinant tumor necrosis factoralpha for AIDS-associated Kaposi's sarcoma: a randomized, double-blind trial. $J$. Acquired Immune Defic. Syndr. 2:217-223.

18. Kovacs, J. A., L. Deyton, R. Davey, J. Faloon, K. Zunch, P. Lee, J. A. Metcalf, J. W. Bigley, L. A. Sawyer, and K. C. Zoon. 1989. Combined zidovudine and interferon-alpha therapy in patients with Kaposi sarcoma and the acquired immunodeficiency syndrome (AIDS). Ann. Int. Med. 111:280-287.

19. Krown, S. E., J. W. Gold, D. Niedzwiecki, D. Bundow, N. Flomenberg, B. Gansbacher, and B. J. Brew. 1990. Interferon-alpha with zidovudine: safety, tolerance, and clinical and virologic effects in patients with Kaposi sarcoma associated with the acquired immunodeficiency syndrome (AIDS). Ann. Int. Med. 112:812-821.

20. Lane, H. C., J. Faloon, R. E. Walker, L. Deyton, J. A. Kovacs, H. Masur, S. Banks, L. E. Kirk, M. W. Baseler, and N. P. Salzman. 1989. Zidovudine in patients with human immunodeficiency virus (hiv) infection and Kaposi sarcoma. Ann. Int. Med. 111:41-50.

21. Miles, S. A., H. J. Wang, E. Cortes, J. Carden, S. Marcus, and R. T. Mitsuyasu. 1990. Beta-interferon therapy in patients with poor-prognosis Kaposi sarcoma related to the acquired immunodeficiency syndrome (AIDS). Ann. Int. Med. 112:582-589.

22. Smith, M. A., D. R. Parkinson, B. D. Cheson, and M. A. Friedman. 1992. Retinoids in cancer therapy. J. Clin. Oncol. 5:839-864.

23. Tallman, M. S., and P. H. Wiernik. Retinoids in cancer treatment. 1992. J. Clin. Pharmcol. 32:868-888.

24. Bollag, W., R. Peck, and J. R. Frey. 1992. Inhibition of proliferation by retinoids, cytokines and their combination in four human transformed epithelial cell lines. Cancer Lett. 62:167-172.

25. Schofield, P. N., M. Granerus, A. Lee, T. J. Ekstrom, and W. Engstrom. 1992. Concentration dependent modulation of basic fibroblast growth factor action on multiplication and locomotion of human teratocarcinoma cells. FEBS (Fed. Eur. Biochem. Soc.) Lett. 298:154-158.

26. Michaeli, J., R. A. Rifkind, and P. A. Marks. 1992. Differentiating agents in cancer therapy. In Cancer Chemotherapy and Biological Response Modifiers. H. M. Pinedo, D. L. Longo, and B. A. Chalmers, editors. Elsevier Science Publishers B. V., Amsterdam. 286-307.

27. Giguere, V., M. Shago, R. Zirngibl, P. Tate, J. Rossant, and S. Varmusa. 1987. Identification of the receptor for the morphogen retinoic acid. Nature (Lond.). 330:624-629.

28. Krust, A., A. Kastner, M. Petkovich, A. Zelent, and P. Chambon. 1989. A third human retinoic acid receptor, hRAR- $\gamma$. Proc. Natl. Acad. Sci. USA. 86:5310-5314.

29. Mangelsdorf, D. J., E. S. Ong, J. A. Dyck, and R. M. Evans. 1990. Receptor that identifies a novel retinoic acid response pathway. Nature (Lond.). 345:224-229.

30. Levin, A. A., L. J. Sturzenbecker, S. Kazmer, T. Bosakowski, C. Huselton, G. Allenby, J. Speck, C. Kratzeisen, M. Rosenberger, A. Lovey, and J. F. Grippo. 1992. 9-cis retinoic acid stereoisomer binds and activates the nuclear receptor $\operatorname{RxR} \alpha$. Nature (Lond.). 355:359-361.

31. Sidell, N., T. Taga, T. Hirano, T. Kishimoto, and A. Saxon. 1991. Retinoic acid-induced growth inhibition of a human myeloma cell line via down-regulation of IL-6 receptors. J. Immunol. 146:3809-3814.

32. Bonhomme, L., G. Fredj, S. Averous, A. M. Szekely, E. Eckstein, B. Trumbic, P. Meyer, J. M. Lang, J. L. Misset, and C. Jasmin. 1991. Topical treatment of epidemic Kaposi's sarcoma with all-trans-retinoic acid (letter). Ann Oncol. 2:234-235.

33. Telford, W. G., L. E. King, and P. J. Fraker. 1992. Comparative evaluation of several DNA binding dyes in the detection of apoptosis-associated chromatin degradation by flow cytometry. Cytometry. 13:137-143.

34. Chomczynski, P., and N. Sacchi. 1987. Single-step method of RNA isolation by acid guanidinium thiocyanate-phenol-chloroform extraction. Anal. Biochem. 162:156-159.

35. Honda, M., K. Kitamura, Y. Mizutani, M. Oishi, M. Arai, T. Okura, K. Igarahi, K. Yasukawa, T. Hirano, and T. Kishimoto. 1990. Quantitative analysis of serum IL-6 and its correlation with increased levels of serum IL-2R in HIV-induced diseases. J. Immunol. 145:4059-4064.

36. Kanai, M., A. Raz, and D. S. Goodman. 1968. Retinol-binding protein: the transport protein for vitamin $A$ in human plasma. J. Clin. Invest. 47:20252044.

37. Peterson, P. A. 1971. Characteristics of a vitamin A transporting protein complex occurring in human serum. J. Biol. Chem. 246:34-43.

38. Siegenthaler, G., J. H. Saurat, and M. Ponec. 1988. Terminal differentiation in cultured human keratinocytes is associated with increased levels of cellular retinoic acid-binding protein. Exp. Cell Res. 178:114-126.

39. Rizzino, A. 1987. Appearance of high affinity receptors for type $\beta$ transforming growth factor during differentiation of murine embryonal carcinoma cells. Cancer Res. 47:4386-4390.

40. Le-Ruppert, K., J. R. W. Masters, R. Knuechel, S. Seegers, M. A. Tainsky, F. Hofstaedter, and R. Buettner. 1991. The effect of retinoic acid on chemosensitivity of PA-1 human teratocarcinoma cells and its modulation by an activated N-ras oncogene. Int. J. Cancer. 51:646-651. 